Musical Echoes

REFIGURING AMERICAN MUSIC

A series edited by Ronald Radano and Josh Kun

Charles McGovern, contributing editor 


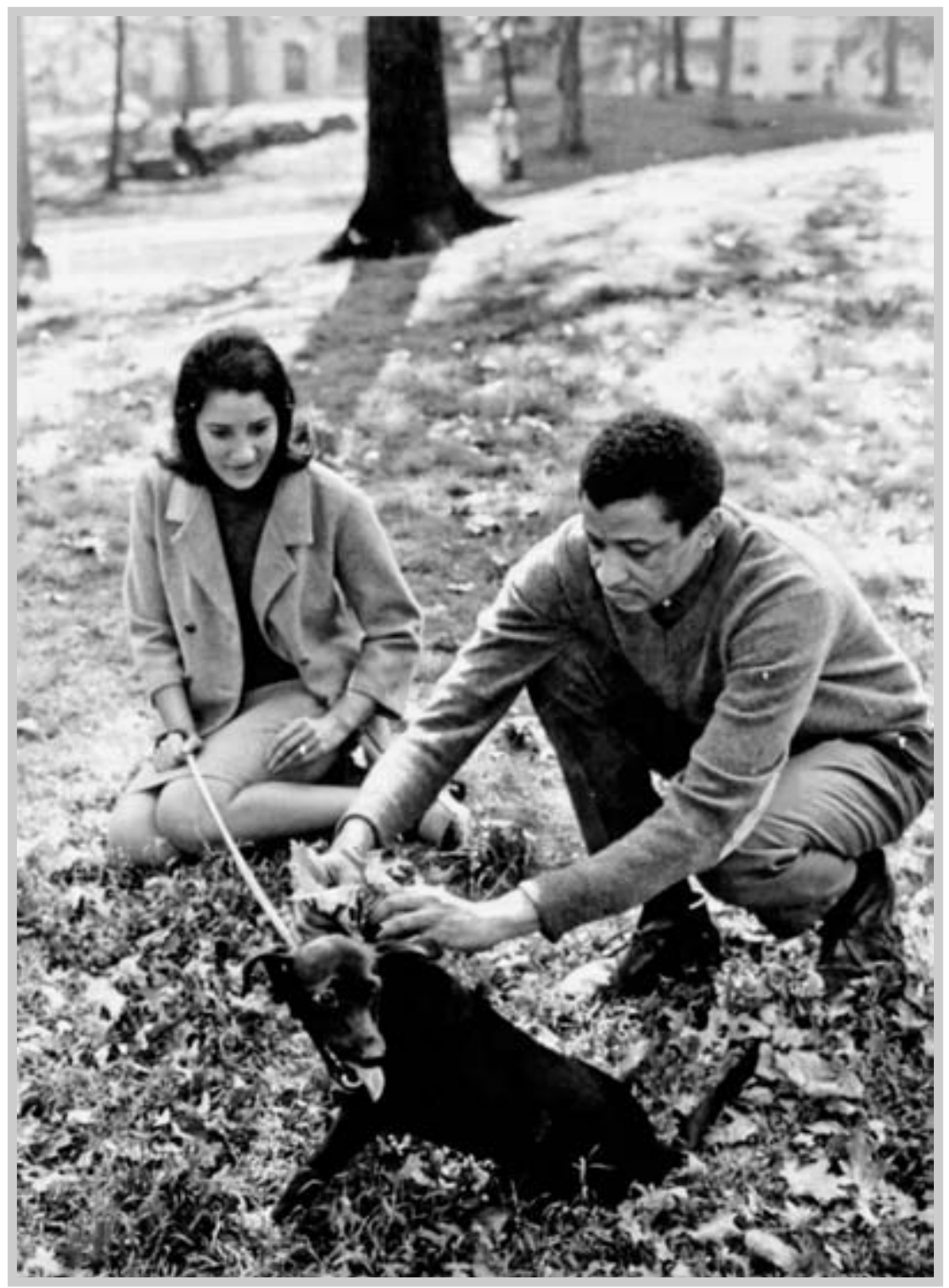

Sathima and Abdullah with Boots the dog in Central Park, mid-196os. Collection of Sathima Bea Benjamin. 


\section{Musical Echoes}

South African Women Thinking in Jazz CAROL ANN MULLER $\mathscr{G}$ SATHIMA BEA BENJAMIN 
(C) 2011 Duke University Press

All rights reserved.

Printed in the United States of America

on acid-free paper @

Designed by C. H. Westmoreland

Typeset in Arno Pro by Tseng Information Systems, Inc.

Library of Congress Cataloging-in-Publication Data

appear on the last printed page of this book.

Duke University Press gratefully acknowledges the support of the LLoyd Hibberd Endowment of the

American Musicological Society, which provided

funds toward the publication of this book.

Short audio clips of Sathima Benjamin's music are available for listening at http://www.africanmusical echoes.org/ as is information on purchasing tracks from Cape Town Love and other Benjamin recordings. 
TO OUR CHILDREN

Tsakwe

Tsidi

Zachary

Jasmine

A Diasporic Generation 
